\title{
Ecohydrological modelling of water discharge and nitrate loads in a mesoscale lowland catchment, Germany
}

\author{
Q. D. Lam, B. Schmalz, and N. Fohrer \\ Dept. Hydrology and Water Resources Management, Ecology Centre, Kiel, Germany \\ Received: 15 January 2009 - Revised: 24 April 2009 - Accepted: 28 April 2009 - Published: 11 August 2009
}

\begin{abstract}
The aims of this study are to identify the capacities of applying an ecohydrological model for simulating flow and to assess the impact of point and non-point source pollution on nitrate loads in a complex lowland catchment, which has special hydrological characteristics in comparison with those of other catchments. The study area Kielstau catchment has a size of approximately $50 \mathrm{~km}^{2}$ and is located in the North German lowlands. The water quality is not only influenced by the predominating agricultural land use in the catchment as cropland and pasture, but also by six municipal wastewater treatment plants.

Ecohydrological models like the SWAT model (Soil and Water Assessment Tool) are useful tools for simulating nutrient loads in river catchments. Diffuse entries from the agriculture resulting from fertilizers as well as punctual entries from the wastewater treatment plants are implemented in the model set-up.

The results of this study show good agreement between simulated and measured daily discharges with a NashSutcliffe efficiency and a correlation coefficient of 0.76 and 0.88 for the calibration period (November 1998 to October 2004); 0.75 and 0.92 for the validation period (November 2004 to December 2007). The model efficiency for daily nitrate loads is 0.64 and 0.5 for the calibration period (June 2005 to May 2007) and the validation period (June 2007 to December 2007), respectively. The study revealed that SWAT performed satisfactorily in simulating daily flow and nitrate loads at the lowland catchment in Northern Germany.
\end{abstract}

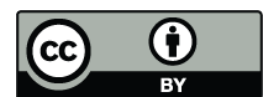

Correspondence to: Q. D. Lam (dlamquang@hydrology.uni-kiel.de)

\section{Introduction}

The degradation of water quality due to non-point source and point source pollution is becoming an increasing global concern. In order to improve the quality of polluted water bodies, the European Framework Directive was implemented in the year 2000 to protect the various types of water bodies in question (EC, 2000). One of the main objectives of the European Framework Directive is for water bodies to achieve a good ecological state by 2015 .

Lowland catchments are ecosystems with low flow velocity, a high ground water table, and flat topography (Müller et al., 2004; Krause et al., 2007; Schmalz et al., 2008). Agricultural practices such as fertilizer and pesticide use as well as sewages are main reasons causing the pollution of stream water in these catchments in Northern Germany. Furthermore the installation of artificial drainage systems and pumping stations have changed the natural water balance considerably and influenced the in-stream water quality due to an accelerated nutrient transport (Schmalz et al., 2008). Many studies have observed that installation of drainage ditches increases the leaching of nutrients. Adamson et al. (2000) reported small changes in nitrate concentrations by installing drainage ditches in blanket peat. Evans et al. (1995) have suggested the implementation of controlled drainage as management practices to minimize nitrate losses. David et al. (1997) have found high nitrate concentrations with the range of 5 to $49 \mathrm{mg} / \mathrm{l}$ in drainage tiles in an agricultural catchment area in Illinois.

For the prediction of hydrological processes and nutrient loads, simulation models that describe the water and nutrient dynamics might be considered as useful tools. A number of ecohydrological models have already been used in lowland catchments: the IWAN model (Krause and Bronstert, 2005) was used for modeling water balance and nutrient dynamics of floodplains. Hattermann et al. (2006) integrated wetlands and riparian zones into SWIM (Krysanova et al., 1998) to

Published by Copernicus Publications on behalf of the European Geosciences Union. 
Table 1. Characteristics of the Kielstau catchment. Information on topography is derived from the DEM, Climate data are taken from Meierwik station (Deutscher Wetterdienst DWD, 2008), and Landuse distribution is taken from Deutsches Zentrum für Luft- und Raumfahrt (DLR, 1995).

\begin{tabular}{llllll}
\hline Parameter & & Value & Parameter & Value \\
\hline Topography & & & Land use class & \\
& Area & $50 \mathrm{~km}^{2}$ & Land use, \% of area $(>2 \%)$ & & \\
& Maximum height difference & $49 \mathrm{~m}$ & & Agriculture & $55.82 \%$ \\
& Mean river slope & $1 \%$ & & Pasture & $26.14 \%$ \\
& Main river length & $17 \mathrm{~km}$ & & Range Brush & $5.64 \%$ \\
Climate & & & & Forest Deciduous & $8.62 \%$ \\
& & & Urban & $3.13 \%$ \\
& Annual precipitation & $841 \mathrm{~mm}$ & Dominant crops & Wheat, Rape, Maize & \\
& Mean annual evapotranspiration & $400 \mathrm{~mm}$ & Demography & & \\
& Mean annual temperature & $8.2^{\circ} \mathrm{C}$ & & Population & 85.955 \\
\hline
\end{tabular}

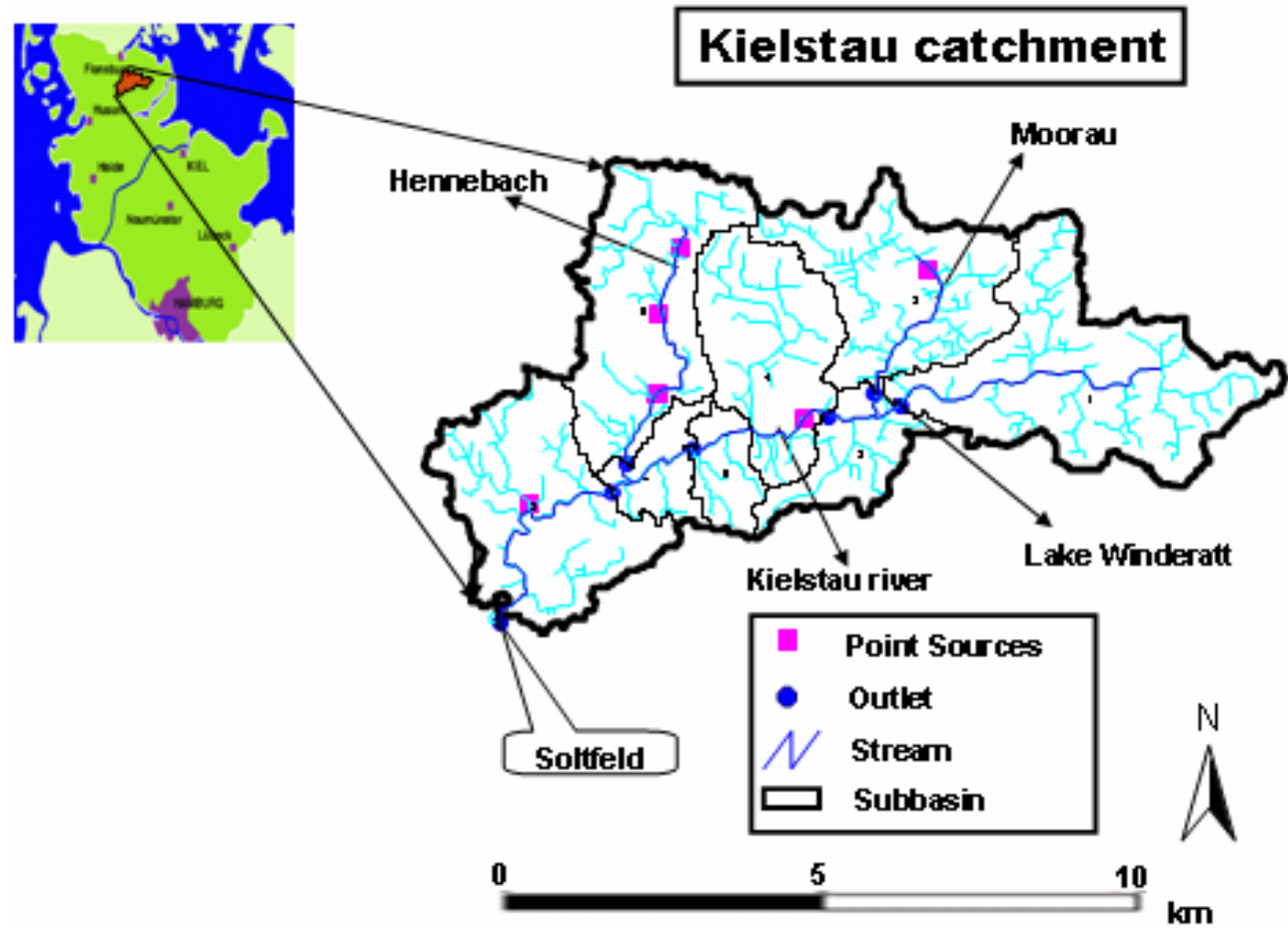

Fig. 1. Location of the Kielstau catchment and its subbasins in Schleswig-Holstein, Northern Germany.

determine their influence on water and nutrient fluxes. The SWAT model (Arnold et al., 1998) has been widely used all around the world to predict stream discharge and nutrient loads from various sizes of watersheds (Tripathi et al. 2004). Borah and Bera (2003) found that SWAT was the most useful for long-term simulation in predominantly agricultural watersheds when they compared eleven hydrologic and non-point source pollution models. In addition, the computational efficiency of SWAT is convenient for parametric adjustment and multiple simulations implemented in minimal time (Arnold and Fohrer, 2005).
The objective of this paper is to evaluate the performance of the SWAT model in simulating water balance and stream discharge in a complex lowland catchment which has special hydrological characteristics in comparison with those of other catchments, and to predict the impact of point and nonpoint source pollution on nitrate loads based on current agricultural practices and sewage disposals at the watershed outlet. 
Table 2. Sensitivity analysis results.

\begin{tabular}{cllcll}
\hline Rank & Parameters & Description* & Rank & Parameters & Description* \\
\hline 1 & GWQMN & Threshold depth of water in shallow aquifer & 8 & SOL_Z & Depth from soil surface to bottom of layer \\
2 & RCHRG_DP & Deep aquifer percolation coefficient & 9 & CH_K & Channel effective hydraulic conductivity \\
3 & ALPHA_BF & Base flow recession constant & 10 & SURLAG & Surface runoff lag coefficient \\
4 & SOL_AWC & Available water capacity & 11 & SOL_K & Saturated hydraulic conductivity \\
5 & ESCO & Soil evaporation compensation factor & 12 & CN 2 & Curve number \\
6 & GW_REVAP & Groundwater revap coefficient & 24 & EPCO & Plant uptake compensation factor \\
7 & GW_DELEY & Delay time for aquifer recharge & 28 & BLAI & Maximum potential leaf area index \\
\hline
\end{tabular}

* Detailed description is available at http://www.brc.tamus.edu/swat/swatdoc.html (Neitsch et al., 2005).

\section{Materials and methods}

\subsection{Study area}

The study area Kielstau catchment is located in Northern Germany as part of a lowland area of Schleswig-Holstein (Fig. 1). The area of the Kielstau catchment is about $50 \mathrm{~km}^{2}$. Land use is dominated by arable land and pasture. The arable land area occupies over 55\%, pasture accounts for $26 \%$ of the total area and urban area makes up over 3\% (Table 1). The soils of the rural catchment are sandy or loamy, and the river valleys are characterized by peat soils.

The Kielstau River has a total length of $17 \mathrm{~km}$ and flows through Lake Winderatt towards the gauge Soltfeld, located at the outlet of the Kielstau catchment (Fig. 1). There are two important tributaries of the Kielstau River from the north, the Moorau and the Hennebach, and wastewater treatment plants have been built in both (Fig. 1). Specifically, one wastewater treatment plant has been built in Moorau tributary, three others in Hennebach tributary and two others in the Kielstau River; all of which can have a remarkable influence on the water quality of the Kielstau River downstream (Schmalz et al., 2007). In addition various small tributaries and water from drainage pipes and ditches flow into the Kielstau River. The drainage fraction of agricultural area in the Kielstau catchment is estimated at 38\% (Fohrer et al., 2007).

\subsection{The SWAT model}

The ecohydrological model SWAT (Soil and Water Assessment Tool, Arnold et al., 1998, version 2005) was applied to simulate both the water balance and the nitrate loads in this complex hydrological catchment. SWAT is a semidistributed, process-oriented hydrological model. It is a continuous time model which simulates water and nutrient cycles with a daily time step. The SWAT model represents the large-scale spatial heterogeneity of the study area by dividing the watershed into subbasins. The subbasins are then further subdivided into hydrologic response units (HRUs) that are assumed to consist of homogeneous land use and soils. Ma- jor components of the model include hydrology, weather, and agricultural management. The details of all components can be found in Arnold et al. (1998) and Neitsch et al. (2002).

In the SWAT model, soil water content, surface runoff, nutrient cycles, crop growth and management practices are simulated for each HRU and then aggregated for the subbasin by a weighted average. The model's hydrological components are comprised of surface runoff, percolation, lateral flow, ground water, evapotranspiration and channel transmission loss. Surface runoff volume is estimated using a modification of Soil Conservation Services (SCS) curve number method (Williams and Laseur, 1976).

The soil profile is subdivided into multiple layers including infiltration, evaporation, plant uptake, lateral flow, and percolation to lower layers. SWAT offers various methods to estimate the potential evapotranspiration (PET) such as Hargreaves, Penman-Monteith, and Priestley. The PenmanMonteith method was chosen in this study because the PET evaluation is based on the basic data such as solar radiation, wind speed, air temperature and relative humidity, whereas wind speed is not considered by the Hargreaves and Priestley methods. The model computes evaporation from soils and plants separately. Potential soil water evaporation is predicted as a function of potential evapotranspiration and leaf area efficiency, while actual soil water evaporation is predicted by using exponential functions of water content and soil depth. Plant transpiration is predicted as a linear function of potential evapotranspiration and leaf area efficiency.

SWAT simulates the nitrogen cycle in the soil profile and in the shallow aquifer (Neitsch et al., 2002). In soil and water, nitrogen is extremely reactive and exists in a number of dynamic forms. It may be added to the soil by rain, mineral and organic fertilizers, residue application, and bacteriological fixation. It can be removed from the soil through plant consumption, soil erosion, leaching, volatilization and denitrification. In the SWAT model, there are five different pools of nitrogen in the soil. Two pools $\left(\mathrm{NH}_{4}^{+}, \mathrm{NO}_{3}^{-}\right)$are inorganic forms of nitrogen, while the other three pools are organic forms of nitrogen. Nitrate may be transported with 
Table 3. Model input data sources for the Kielstau watershed.

\begin{tabular}{lll}
\hline Data type & Source & Data description/properties \\
\hline Topography & LVermA, 1995 & Digital elevation model, a grid size of 25 m $\times 25 \mathrm{~m}$ \\
Soil map & BGR, 1999 & Soil physical properties such as texture, saturated conductivity, etc. Scale of soil map (1:200 000) \\
Landuse map & DLR, 1995 & Land use classifications, 25 m $\times 25 \mathrm{~m}$ resolution \\
Climate data & DWD, 2008 & Temperature, precipitation, wind speed, humidity, (Meierwik station, 1993-2007) \\
Sewage disposal & Kreis Schleswig-Flensburg, 2007 & Sewage disposal (point sources) data of 6 waste water treatment plants (Fig. 1) \\
Hourly discharge & Staatliches Umweltamt Schleswig, 2008 & Hourly discharge data of Kielstau at gauge Soltfeld, (1993-2007) \\
\hline
\end{tabular}

surface runoff, lateral flow or percolation. The amount of nitrate moving with the water is calculated by multiplying the concentration of nitrate in the mobile water by the volume of water moving in each pathway.

Since nitrate fluxes strongly depend on water fluxes, parameters controlling water balance were calibrated as the first step, and only then were nitrate loads considered. The application of the model first involved the analysis of parameter sensitivity, which was then used for model auto-calibration following the hierarchy of sensitive model parameters. The sensitivity analysis method (Morris, 1991) was conducted and aims to assess the most sensitive parameters for setting up the model in this catchment (Table 2). Model autocalibration was performed by changing each parameter ten times within the allowable range of values for the specific parameter. Detailed calibration procedures for SWAT model and the definitions of various calibration parameters are described by Neitsch et al. (2002).

The auto-calibration was carried out using daily flow data of the hydrological years 1998-2004. The validation was done for the continuous time 2004-2007. For the nitrate loads simulation, the manual calibration was performed for a period of two years (June 2005-May 2007) after which the validation was done for a period of six months (June 2007December 2007).

The performance of the model was evaluated by the NashSutcliffe efficiency (Nash and Sutcliffe, 1970), correlation coefficient, and root mean square error to determine the quality and reliability of the predictions compared to measured values.

\subsection{Input data}

The main input data used for the SWAT model are shown in Table 3. A three-year crop rotation (winter wheat winter wheat - rape) and monocultural maize were simulated on arable land. Fertilizer application and cultivation schedule are in conformance with the conventional cultivation (Table 4). Measured nitrate concentrations from June 2005 to December 2007 (weekly data for the year 2005 and daily data for the years from 2006 to 2007) were collected and analyzed by the Department of Hydrology and Water Resources Management-Ecology Centre at Kiel University (Tavares, 2006 and Bieger, 2007). Data of average monthly point source effluents from January 2002 to December 2007 (Kreis Schleswig-Flensburg, 2007) were implemented as point sources in the model.

\section{Results and discussion}

Parameters that significantly affected water balance have been adjusted in their values in order to provide the best fit between the measured and simulated data by the autocalibration tool of the model. These parameters include the SCS runoff curve number for moisture condition II, available water capacity, soil evaporation compensation factor, groundwater parameters, and channel effective hydraulic conductivity. For instance, soil evaporation compensation factor, the groundwater revap coefficient, and depth-tosubsurface drain have been adjusted from the default values of $1 ; 0.02 ; 0$ to the simulated values of $0.95 ; 0.2 ; 800$, respectively. Groundwater revap coefficient is an important parameter controlling the upwelling of groundwater into the unsaturated soil zone. The allowable range of this parameter is between 0.02 and 0.2. As the groundwater revap coefficient approaches 0 , movement of water from the shallow aquifer to the root zone is restricted. For the Kielstau catchment, this parameter was changed from its initial value of 0.02 to 0.2 in order to obtain a better fit of the model results to the measured data. The auto-calibration processes were also implemented similarly for other parameters within their allowable range in SWAT.

Figure 2 shows good agreement between simulated and measured daily discharge with a Nash-Sutcliffe efficiency and a correlation coefficient of 0.76 and 0.88 for the calibration period and 0.75 and 0.92 for the validation period at the outlet of Kielstau catchment, respectively. Overall, the model performance was satisfactory in both calibration and validation periods in daily time step.

The model results for daily nitrate loads at the gauge Soltfeld are illustrated in Fig. 3. Parameters which remarkably impacted the nitrate concentrations such as humus mineralization (CMN), Nitrogen percolation coefficient (NPERCO), and residue mineralization (RSDCO) have been manually adjusted so that the prediction corresponds to the measured values during the calibration period (Table 5). 
Table 4. Crop types and fertilization for different land use classes of the Kielstau catchment.

\begin{tabular}{|c|c|c|}
\hline \multicolumn{3}{|c|}{$\begin{array}{l}\text { Crop rotation ( } 3 \text { years): winter wheat - winter wheat - rape } \\
\text { Monocultural maize }\end{array}$} \\
\hline Crops & Date of fertilizer application & Total fertilization \\
\hline Winter Wheat & 15 March; 15 April; 15 June & 220 (kg N/ha); 240 (kg manure/ha) \\
\hline Rape & 20 March; 15 April & $200(\mathrm{~kg} \mathrm{~N} / \mathrm{ha})$ \\
\hline Maize & 20 March; 1 May; 10 June; 10 August & 180 (kg N/ha) ; 300 (kg manure/ha) \\
\hline Pasture & 15 March; 30 May; 10 July; 25 August & 160 (kg N/ha) \\
\hline Range Brush & 1 March & 80 (kg N/ha) \\
\hline
\end{tabular}

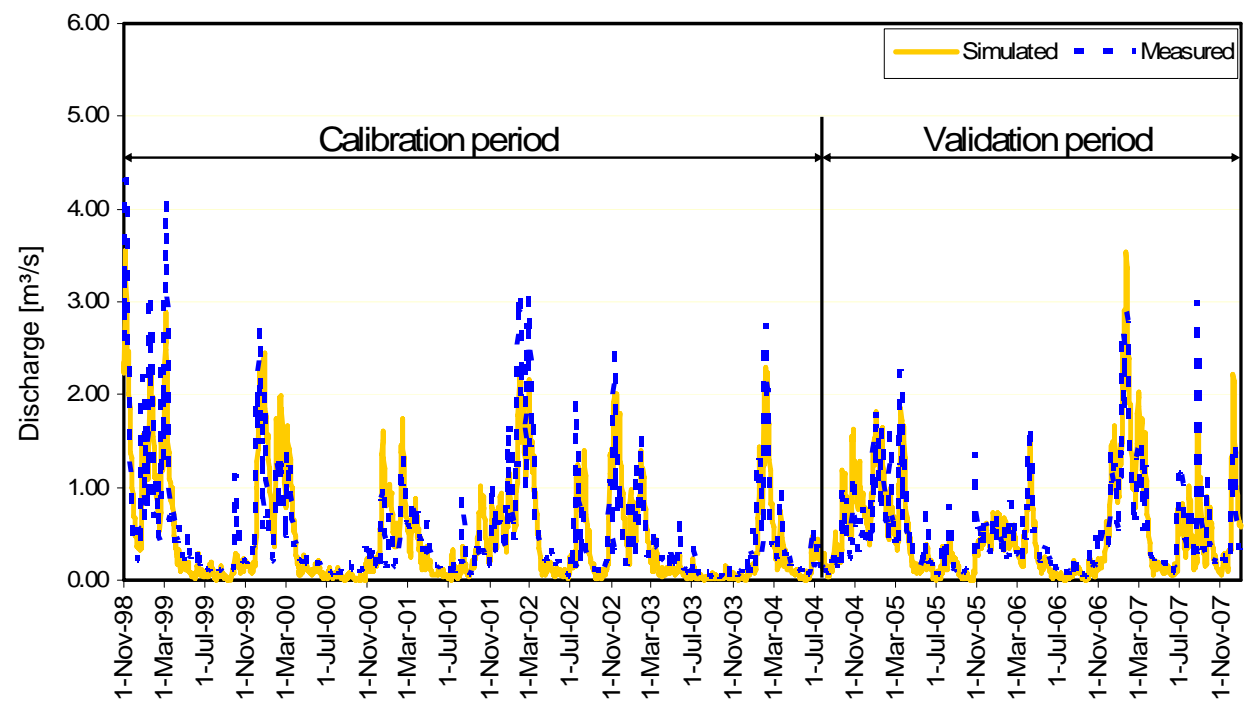

Fig. 2. Measured and simulated daily discharge at the Kielstau catchment outlet, gauge Soltfeld (Nash-Sutcliffe efficiency and correlation coefficient of 0.76 and 0.88 for the calibration period; 0.75 and 0.92 for the validation period).

Table 5. Calibrated parameters with SWAT model for simulating nitrate loads.

\begin{tabular}{llll}
\hline Parameter & Process & Initial & Final \\
\hline CMN & Humus mineralization & 0.0003 & 0.002 \\
NPERCO & Nitrogen percolation coefficient & 0.2 & 0.95 \\
RSDCO & Residue mineralization & 0.01 & 0.05 \\
BIOMIX & Biological mixing efficiency & 0.2 & 0.1 \\
\hline
\end{tabular}

During the summer periods of 2005, 2006, and 2007 the model simulated well for both the range and the dynamic of the nitrate loads in general. In contrast, the model underpredicted the nitrate loads during the winter periods. This can be attributed to the following main reasons: Firstly, the underestimation of some peak flows led to the underestimation of the corresponding nitrogen peaks. Secondly, the higher nitrogen concentrations in the winter caused by nitrogen mobilization from the catchment are not represented in the model. Thirdly, the lack of plant uptake which causes accumulation of leachable nitrate resulted in increasing nitrogen concentrations in stream flow during the winter period.

For the winter period of 2005, the disagreement between measured and simulated nitrate loads was due to the underestimation of discharge. Furthermore the measured data of nitrate loads were only collected once a week in this period, while the model outputs were daily nitrate loads. The marked difference of weekly and daily resolution may influence the model efficiency in the whole simulation period.

The Nash-Sutcliffe efficiency and the correlation coefficient of the nitrate model are 0.64 and 0.86 for the calibration period and 0.5 and 0.71 for the validation period, respectively. These results are in accordance with previous studies using SWAT on various catchments. Bieger (2007) simulated daily nitrate loads on the same catchment and obtained a Nash-Sutcliffe efficiency and a correlation coefficient of 0.55 and 0.84 for the calibration period of June 2005-October 2006, respectively. However, differing from 


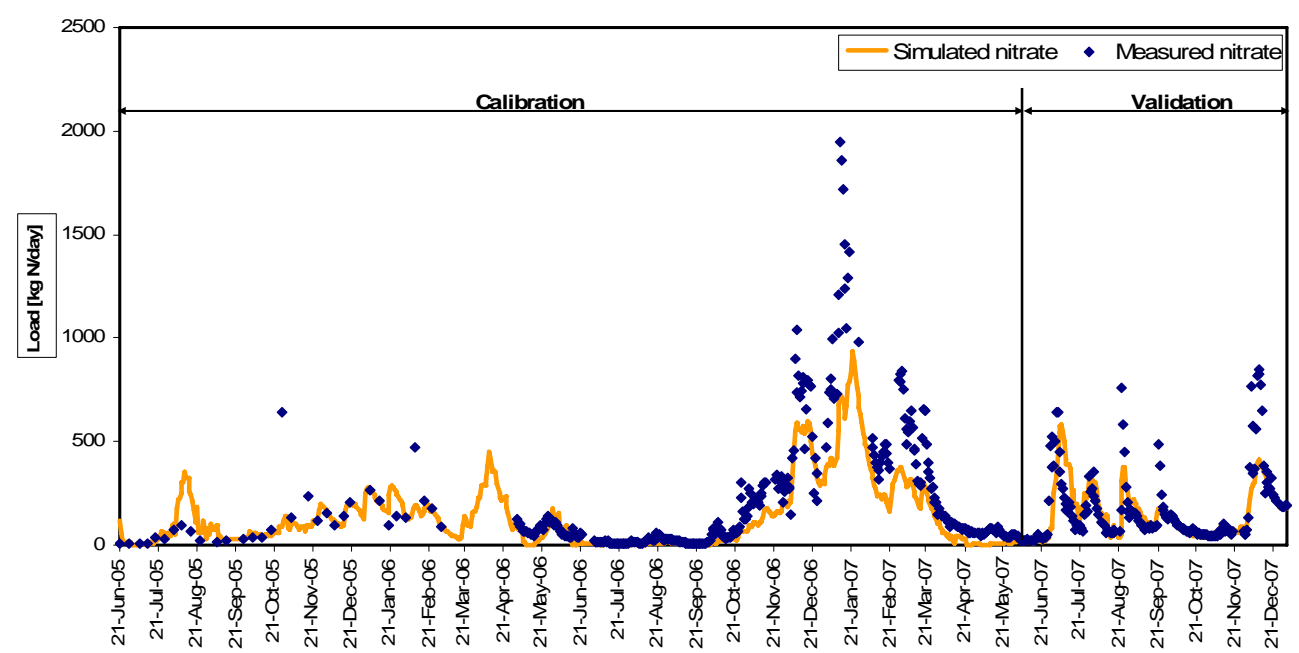

Fig. 3. Measured and simulated daily nitrate loads at the Kielstau catchment outlet, gauge Soltfeld (Nash-Sutcliffe efficiency, correlation coefficient, and root mean square error of $0.64,0.86$, and 96.9 for the calibration period; $0.5,0.71$, and 67.5 for the validation period).

the present study, point source effluents were used as input data for constant daily loading by Bieger (2007). Grizzetti et al. (2003) obtained a Nash-Sutcliffe efficiency of 0.51 when they used SWAT to model diffuse emissions and retentions of nutrients on daily time step at the Vantaanjoki watershed $\left(1680 \mathrm{~km}^{2}\right)$, which is situated in Southern Finland and classified as a lowland catchment. Behera and Panda (2006) concluded that SWAT simulated nitrate concentration satisfactorily throughout the entire rainy season based on comparisons with daily-observed data from an agricultural watershed located in eastern India. They obtained a Nash-Sutcliffe efficiency and a correlation coefficient of 0.92 and 0.93 for the calibration period, respectively.

With the above outlined results, we achieved a comparable simulation efficiency of daily nitrate loads. The simulated results indicated that the SWAT model was applied to simulate seasonable daily nitrate loads in the Kielstau catchment.

\section{Conclusions}

The ecohydrological SWAT model has been used to simulate both water balance and nitrate loads from different point and non-point sources in the mesoscale Kielstau catchment - a typical lowland area in Northern Germany. The basis input data comprises climate, land use, soil, topography, and current agricultural data as well as sewage disposals of six wastewater treatment plants were used in this study to predict the current nitrate loads. The simulated flow and nitrate loads were compared with corresponding in-stream measurements at the Soltfeld station of Kielstau catchment. The results of this study show good agreement between simulated and measured daily discharges with a Nash-Sutcliffe efficiency and a correlation coefficient of 0.76 and 0.88 for the calibration period and 0.75 and 0.92 for the validation period.
The statistical coefficients of the nitrate model performance were relatively reasonable (Nash-Sutcliffe efficiency, correlation coefficient of $0.64,0.86$ for the calibration period; 0.5 , 0.71 for the validation period, respectively) and demonstrate that SWAT results are reliable at a daily time scale for nitrate loads. Overall, SWAT performed satisfactorily in simulating both daily flow and nitrate loads at the Kielstau catchment.

In our ongoing research, the measured data of nitrate concentration will be continuously expanded and used to increase the validation period of nitrate loads. It is expected that a wider range of data will prove helpful in more clearly understanding the trend of nitrate loads. Furthermore, different management practice scenarios will be considered with the goal of minimizing nitrate loads in the long term.

Edited by: B. Schmalz, K. Bieger, and N. Fohrer

Reviewed by: R. Ludwig and F. Wimmer

\section{References}

Adamson, J. K., Scott, W. A., Rowland, A. P., and Beard, G. R. Ionic concentrations in blanket peat bog in northern England and correlations with deposition and climatic variables, Eur. J. Soil Sci., 51, 1-15, 2000.

Arnold, J. G. and Fohrer, N.: SWAT 2000: Current capabilities and research opportunities in applied watershed modeling, Hydrol. Proc. 19, 563-572, 2005.

Arnold, J. G., Srinivasan, R., Muttiah, R. S., and Williams, J. R.: Large area hydrologic modelling and assessment, Part I: Model development, J. Am. Water Resour. Assoc., 34(1), 73-89, 1998.

Behera, S. and Panda, R. K.: Evaluation of management alternatives for an agricultural watershed in a sub-humid subtropical region using a physical process model, Agric. Ecosyst. Environ., 113(14), 62-72, 2006 
Bundesanstalt für Geowissenschaften und Rohstoffe (BGR)(Ed.): Bodenübersichtskarte im Maßstab 1:200000, Verbreitung der Bodengesellschaften, Hannover, Germany, 1999.

Bieger, K.: Integrierte Analyse der Wasserqualität eines Fließgewässers im ländlich geprägten Raum des Norddeutschen Tieflands, Diplomarbeit im Fach Geographie, ÖkologieZentrum Christian-Albrechts-Universität zu Kiel. p. 142, http://www.hydrology.uni-kiel.de/lehre/abschlussarbeiten/ 2008_kbieger_kielstauqualitaet.pdf, 2007.

Borah, D. K. and Bera, M.: Watershed-scale hydrologic and nonpoint source pollution models: review of mathematical bases, T. ASAE, 46(6), 1553-1566, 2003.

David, M. B., Gentry, L. E., Kovacic, D. A., and Smith, K. M.: Nitrogen balance in and export from an agricultural watershed, J. Environ. Qual., 26(4), 1038-1048, 1997.

DLR (Deutsches Zentrum für Luft- und Raumfahrt): Landsat TM5Scene of 1995, upper left corner: RW: 3503180 HW: 6084975, spatial resolution $25 \mathrm{~m} \times 25 \mathrm{~m}$, Köln, Germany, 1995 .

DWD (Deutscher Wetterdienst): Climate data 1993-2007, 2008.

EC: Directive 2000/60/EC of the European Parliament and of the Council of 23 October 2000 establishing a framework for Community action in the field of water policy, Off. J. Eur. Communities, L327.

Evans, R. O., Gilliam, J. W., and Skaggs, R. W.: Controlled versus conventional drainage effects on water quality, J. Irrig. Drain, E.ASCE, 121(4), 271-276, 1995.

Fohrer, N., Schmalz, B., Tavares, F., and Golon, J.: Ansätze zur Integration von landwirtschaftlichen Drainagen in die Modellierung des Landschaftswasserhaushalts von mesoskaligen Tieflandeinzugsgebieten, Hydrol. Wasserbewirtsch., 51(4), 164169,2007

Grizzetti, B., Bouraoui, F., Granlund, K., Rekolainen, S., and Bidoglio, G.: Modelling diffuse emission and retention of nutrients in the Vantaanjoki watershed (Finland) using the SWAT model, Ecol. Modell., 169, 25-38, 2003.

Hattermann, F. F., Krysanova, V., Habeck, A., and Bronstert, A.: Integrating wetlands and riparian zones in river basin modeling, Ecol. Modell., 199(4), 379-392, 2006.

Krause, S. and Bronstert, A.: An advanced approach for catchment delineation and water balance modeling within wetlands and floodplains, Adv. Geosci., 5, 1-5, 2005, http://www.adv-geosci.net/5/1/2005/.

Krause, S., Bronstert, A., and Zehe, E.: Groundwater-surface water interactions in a North German lowland floodplain - implications for the river discharge dynamics and riparian water balance, J. Hydrol., 347, 404-417, 2007.

Kreis Schleswig-Flensburg: Kläranlagen-Einleiterdaten, FD Wasserwirtschaft, Schleswig, Germany, 2007.
Krysanova, V., Müller-Wohlfeil, D. I., and Becker, A.: Development and test of a spatially distributed hydrological / water quality model for mesoscale watersheds, Ecol. Modell., 106(1-2), 261-289, 1998.

LVermA (Landesvermessungsamt Schleswig-Holstein): Digitales Geländemodell für Schleswig-Holstein. Quelle: TK25. Gitterweite $25 \mathrm{~m} \times 25 \mathrm{~m}$ und TK 50 Gitterweite $50 \mathrm{~m} \times 50 \mathrm{~m}$, Kiel, 1995.

Morris, M. D.: Factorial sampling plans for preliminary computational experiments, Technometrics, 33(2), 161-174, 1991.

Müller, L., Behrendt, A., and Schindler, U.: Structure aspects of the soil landscape and soil properties of two lowland sites in NorthEast Germany, Archives of Agron. Soil Sci., 50(3), 289-307, 2004.

Nash, J. E. and Sutcliffe, J. V.: River flow forecasting through conceptual models part I - A discussion of principles, J. Hydrol., 10(3), 282-290, 1970.

Neitsch, S. L., Arnold, J. G., Kiniry, J. R., Williams, J. R., and King, K. W.: Soil and Water Assessment Tool Theoretical Documentation Version 2000. GSWRL Report 02-01, BRC Report 02-05, TR-191. Texas Water Resources Institute, College Station, Texas, 2002.

Neitsch, S. L., Arnold, J. G., Kiniry, J. R., and Williams, J. R.: Soil and Water Assessment Tool Theoretical Documentation, Version 2005. Temple, Tex.: USDA-ARS Grassland, Soil And Water Research Laboratory, available at: www.brc.tamus.edu/swat/doc. html, last access: 1 November 2006, 2005.

Schmalz, B., Bieger, K., and Fohrer, N.: A method to assess instream water quality - the role of nitrogen entries in a North German rural lowland catchment, Adv. Geosci., 18, 37-41, 2008, http://www.adv-geosci.net/18/37/2008/.

Schmalz, B., Tavares, F., and Fohrer, N.: Assessment of nutrient entry pathways and dominating hydrological processes in lowland catchments, Adv. Geosci., 11, 107-112, 2007, http://www.adv-geosci.net/11/107/2007/.

Staatliches Umweltamt Schleswig: Hourly discharge data 19932007, 2008.

Tavares, F.: Continuous, spatially distributed, stream flow and quality assessment of a lowland catchment in Northern Germany. Master thesis in "Environmental Management", Ecology Centre Kiel University, p. 134, http://www.hydrology.uni-kiel.de/lehre/ abschlussarbeiten/msc_tavares.pdf, 2006.

Tripathi, M. P., Panda, R. K., Raghuwanshi, N. S., and Singh, R.: Hydrological modeling of a small watershed using generated rainfall in the soil and water assessment tool model, Hydrol. Process., 18, 1811-1821, 2004.

Williams, J. R. and Laseur, W. V.: Water yield model using SCS curve number, J. Hydr. Eng. Div.-ASCE, 102, 1241-1253, 1976. 